\title{
Factors Associated with Depressive Symptoms in the Elderly with Hearing Impairment
}

\author{
Youngmee Lee', Sungil Park ${ }^{2,3}$, Soo Jung Lee ${ }^{2}$ \\ 1 Department of Communication Disorders, Ewha Womans University, Seoul, Korea \\ ${ }^{2}$ Department of Speech-Language Pathology and Audiology, Tongmyong University, Busan, Korea \\ ${ }^{3}$ Park Sungil Aural Rehabilitation and Speech Center, Busan, Korea
}

Received: October 22, 2019

Revised: December 12, 2019

Accepted: December 28, 2019

Correspondence:

Soo Jung Lee, PhD

Department of Speech-Language

Pathology and Audiology,

Tongmyong University,

428 Sinseon-ro, Nam-gu,

Busan 48520, Korea

Tel: +82-51-629-2138

Fax: +82-51-629-2019

E-mail: sjslp@tu.ac.kr
Purpose: The purpose of this study was to examine factors associated with depressive symptoms in the elderly with hearing impairment. Methods: We studied 23 hearing-impaired elderly persons aged 60 years or older. The participants underwent audiometric, neuropsychological, and depression assessments. Neuropsychological tests were subsumed in specific cognitive domains (general cognition, semantic memory, processing speed, executive function). The short version of the geriatric depression scale was administered to obtain depressive symptom scores for each subject. Results: First, among audiometric variables, the pure-tone threshold average, sentence-in-noise recognition scores, and hearing handicap scores were significantly correlated with the depressive symptom scores. Second, among neuropsychological variables, the reaction time on the part A of the Korean version of trail making test for the elderly (K-TMT-E), which is reflective of processing speed, was correlated with the depressive symptom scores. Also, the reaction time on the part B of the K-TMT-E, which is reflective of executive function, was correlated with the depressive symptom scores. Lastly, in the stepwise regression analysis, the pure-tone threshold average and the reaction time on the part B of the K-TMT-E were found to be factors significantly associated with depressive symptom scores. Conclusion: Our findings suggest that, for the hearing-impaired elderly, hearing threshold levels and executive function, especially cognitive flexibility are significant factors associated with depression levels.

Key Words: Depressive symptoms, Elderly, Executive function, Hearing impairment, Hearing threshold levels.

\section{INTRODUCTION}

우리나라는 2017년을 기점으로 전체 인구 중 만 65세 이상 의 고령 인구가 약 $14.2 \%$ 를 차지하는 고령 사회(aged society) 에 진입하였다(Statistics Korea, 2018). 급격한 고령화와 더불어 노인에서 나타나는 각종 만성 질환, 노인 빈곤, 우울 및 자살 등 의 노인 관련 문제들은 심각한 사회적 현안으로 대두되고 있는 데, 특히 노년기 우울은 질병 부담(disease burden)을 높이는 주 요 원인으로 꼽히고 있다. 노인 등의 우울 유병률은 연구마다 다 소 차이를 보이는데, 만 65세 이상의 지역사회 거주 노인의 경우 약 8 15\%의 유병률을 나타내며, 병원이나 전문 요양시설 입원

(c) This is an Open Access article distributed under the terms of the Creative Commons Attribution Non-Commercial License (https://creativecommons.org/licenses/by-nc/4.0) which permits unrestricted non-commercial use, distribution, and reproduction in any medium, provided the original work is properly cited.
환자의 경우 약 30 40\%의 유병률을 나타낸다(Huang et al., 2010). 노년기에 않게 되는 다양한 만성 질환들은 이러한 노인 우울을 증가시키는 주요 원인이 되고 있는데(Huang et al., 2010), 그중 노인성 난청이 우울에 미치는 영향에 관하여 지속 적인 연구가 이루어지고 있다(Mener et al., 2013).

노인성 난청은 노화에 따른 감각신경성 질환으로서, 노인 인 구에서 나타나는 만성 질환 중 하나이다(Gates \& Mills, 2005). 우리나라의 경우 양측성 난청 유병률이 50 대 $2.9 \%, 60$ 대 $12.1 \%$, 70대 이상에서는 $31.7 \%$ 에 이르고 65 세 이상 인구에서는 약 25.9\%의 유병률을 나타낸다(Korea Centers for Disease Control and Prevention, 2012). 또한 65세 이상 노인의 청력 손상 위험은 40세 미만의 초기 성인 집단에 비해 57.68배에 이른다(Kim \& Lee, 2011). 노인성 난청은 노년층의 일상생활 듣기 어려움을 유발하는 주요 요인 중 하나로서(Gates \& Mills, 2005) 이러한 
지각적 어려움은 대인관계 기피 및 사회적 고립으로 이어져 노 인의 심리적 소외감을 유발하고 우울증과 같은 정신과적 문제 를 야기할 수 있다(Strawbridge et al., 2000). Chun et al.(2005) 에 따르면 65 세 이상 노인에서 난청 집단은 정상 청력의 집단에 비해 우울 점수가 더 높았으며, 특히 중도 난청군에서 우울 정도 가 가장 높게 나타났다. 국내의 고령화연구패널조사를 이용한 연구에서도 65 세 이상 노인 집단의 경우 난청이 있을 때 우울 위 험이 약 2.07배 높아지는 것으로 나타났다(Kim et al., 2011).

이처럼 난청 노인이 정상 청력의 노인과 비교하여 우울을 나 타낼 위험성이 크다는 점은 이미 밝혀진 사실이나 난청 노인 집 단 내에서 어떤 요인들이 우울에 영향을 미치는지에 대해서는 선행연구가 부족하다. 난청 노인을 대상으로 한 일부 연구들에서 청력 손실의 정도가 심할수록 우울 점수가 증가하였으며(Chun et al., 2005; Kim et al., 2015) 청력 손실로 인해 난청 노인이 일상생활에서 경험하는 주관적 장애 정도가 우울과 관련성이 있음이 보고되었다(Lee et al., 2019). 또한 최근 연구들을 통해 보청기 착용 여부가 난청자의 우울에 영향을 미친다는 점이 밝 혀진 바 있다(Choi et al., 2016).

노년층의 경우 난청과 같은 감각기능의 저하뿐만 아니라 정 상 노화로 인한 인지기능 감퇴를 겪게 되는데, 이러한 인지기능 감퇴가 노인의 우울에 영향을 미친다는 점은 이미 잘 알려진 사 실이다(McDermott \& Ebmeier, 2009). 여러 선행연구들을 통해 우울을 않는 노인의 경우 전반적 인지능력이 저하된다는 점이 밝혀진 바 있다. 특히, 주로 전전두피질(prefrontal cortex)이 담 당하는 집행기능, 주의 집중 및 정보처리속도 등의 측면에서 뚜 렷한 결함을 보이는데(Elderkin-Thompson et al., 2009; McDermott \& Ebmeier, 2009) 뇌영상 연구들을 통해 우울 환자 의 배외측 전전두피질(dorsolateral prefrontal cortex) 및 전대 상피질(anterior cingulate cortex)의 부피가 감소되어 있으며 이 들 영역에서의 뇌 혈류 및 대사(metabolism)가 저하된다는 점 이 일관적으로 보고되었다(Bremner et al., 2004; ElderkinThompson et al., 2009). 또한 우울의 정도가 심할수록 집행기 능 및 정보처리속도가 저하되며(Cataldo et al., 2005; Naismith et al., 2003), 집행기능 및 정보처리속도와 같은 전두엽이 주로 관여하는 인지 영역에서의 결함 외에도 우울 환자의 경우 의미 기억 역시 저하된다는 점이 일부 선행연구들에서 확인된 바 있 다(Naismith et al., 2003). 그러나 이러한 우울과 인지기능 간 관련성이 난청 노인 집단에서도 유효한지, 그리고 하위인지 영 역별로 어떠한 차이를 나타내는지에 대해서는 아직 구체적으 로 밝혀진 바가 없다.

난청 노년층의 경우 우울 정도가 심할수록 재활에 대한 의지 가 부족하여 난청을 그대로 방치하거나, 혹은 적절한 보장구 착용이 제대로 이루어지지 않을 가능성이 높다. 더불어 제한적
인 사회활동 참여로 인해 청각기능의 활용 정도가 낮아져 이로 인해 치매 등의 인지장애 발병 위험이 높아질 수 있다(Strawbridge et al., 2000). 이에 난청 노인의 우울에 영향을 미치는 주된 요인을 파악하여 이를 중재 시에 고려함으로써 보다 포괄 적이고 효과적인 청각장애 재활이 가능할 수 있을 것으로 기대 한다. 또한 노인 우울이 치매 발병에 대한 위험인자 중 하나라 는 점(Byers \& Yaffe, 2011)을 고려할 때 예방적 측면에서의 중 재 역시 가능하리라 기대한다.

이에 따른 본 연구의 구체적인 목적은 다음과 같다. 첫째, 인 구통계학적 변인(연령, 성별, 교육 수준), 청력 관련 변인(평균순 음역치, 소음 상황에서의 문장인지도, 주관적 청력장애 정도, 평균 보청기 착용 시간), 인지 관련 변인(전반적 인지능력, 의미 기억, 정보처리속도, 집행기능) 가운데 난청 노인의 우울과 상 관이 있는 변인이 무엇인지 알아보고자 하였다. 둘째, 난청 노인 의 우울과 유의한 상관이 나타난 변인들 가운데 우울에 영향 을 미치는 주요 변인이 무엇인지 밝히고자 하였다.

\section{MATERIALS AND METHODS}

\section{연구 대상}

본 연구는 부산시에 위치한 청각재활센터를 내원한 난청 노 인을 대상으로 시행되었다. 난청 노인의 선정기준은 1) 연령이 만 60세 이상이며, 2) 기초건강 선별을 위한 설문에서 신경학 적, 정신적 질환의 병력이 없고 난청 외 이명, 어지러움 등을 호 소하지 않으며, 3) 순음청력검사(AD629, Interacoustics A/S, Middelfart, Denmark)상 500, 1,000, 2,000, 4,000 Hz 주파수 의 평균순음역치가 $26 \mathrm{~dB} \mathrm{HL}$ 이상이고 양측 귀의 평균순음역 치 차이가 $20 \mathrm{~dB} \mathrm{HL}$ 이내로 대칭적이며, 기도-골도 청력 역치 가 $10 \mathrm{~dB} \mathrm{HL}$ 이내에 임피던스 청력검사(AT235, Interacoustics $\mathrm{A} / \mathrm{S})$ 에서 중이의 상태가 정상적인 감각신경성 난청을 나타내 며, 4) 일측 혹은 양측 귀에 보청기를 착용하고 있으며, 5) 한국 판 간이정신상태검사(Korean-mini mental state examination, $\mathrm{K}-\mathrm{MMSE}$ )의 점수가 연령 및 교육연수 규준 비교 시에 -1 표준 편차 이내로 정상 범주에 해당하고(Kang, 2006), 6) 교육연수 가 최소 6 년 이상인 자로 선정하였다. 대상자의 교육연수를 최 소 6년 이상으로 제한함으로써 학력이 인지검사에 미치는 영 향을 최소화하였으며, 시각보조기구를 착용하고도 글자를 읽 을 수 없거나 보청기를 착용하고도 조용한 환경에서 일상생활 대화가 불가능한 경우는 대상에서 제외하였다.

연구 참여를 희망한 총 38 명 가운데 $\mathrm{K}-\mathrm{MMSE}$ 점수가 -1 표 준편차 이하로 저하되는 10 명, 보청기를 착용하지 않는 4 명, 그 리고 인지검사에서 색깔 지각능력의 결함이 의심되는 1 명, 총 15 명이 제외되어 결과적으로 총 23 명이 본 연구의 분석 대상으 
Table 1. Demographic characteristics of participants

\begin{tabular}{lc}
\hline \multicolumn{1}{c}{ Characteristic } & HI $(\mathrm{n}=23)$ \\
\hline Age (years) & $77.26(5.19)$ \\
Gender (M:F) & $16: 7$ \\
Education level (years) & $9.65(3.19)$ \\
SGDS & $5.30(4.43)$ \\
\hline
\end{tabular}

Values are presented as number or mean (standard deviation). HI: hearing impairment, SGDS: short version of geriatric depression scale

로 포함되었다. 연구 대상자의 인구통계학적 변인에 대한 기술 통계 결과는 Table 1에 제시하였다.

\section{연구 도구}

\section{우울 평가}

난청 노인의 우울 증상을 평가하기 위하여 한국어판 단축형 노인우울척도(short version of geriatric depression scale, SGDS) (Cho et al., 1999)를 시행하였다. 한국어판 SGDS는 노인 우울증 선별검사 도구로써 영어 버전의 원 검사도구인 SGDS (Sheikh \& Yesavage, 1986)에 대해 한국어 번역의 표준화 과정을 거친 후 신뢰도 및 타당도 검증을 통해 주요 우울증(major depression)에 대한 진단적 타당성이 확인되었다(Cho et al., 1999). 총 30 개의 문항으로 이루어진 노인우울척도(geriatric depression scale, GDS)에 비해 SGDS는 총 15 개의 문항으로 구성되어 짧 은 시간 내 보다 효율적으로 노인 우울 증상을 측정할 수 있으 며, GDS와의 높은 상관관계 $(\mathrm{r}=0.959)$ 및 신뢰도와 타당도가 입증된 바 있다(Cho et al., 1999). 피검자는 총 15 개의 질문에 대하여 '예' 또는 '아니오'로 응답하게 되는데, 피검자가 문항 내 용을 잘 이해하여 응답하는지 확인하기 위하여 검사자가 문항 을 읽으면서 질문하면 피검자가 구두로 대답하는 방식으로 검 사를 진행하였다. 점수가 높을수록 우울 증상이 심한 것으로 해석하며, SGDS상에서 매우 우울한 상태를 나타내는 최고 점 수는 15 점이다.

\section{청력 평가}

본 연구에서는 청력 평가로 순음청력검사, 소음 상황에서의 문장인지도검사, 주관적 청력장애 정도를 평가하였다. 연구 대 상자의 청력 관련 변인에 대한 기술통계 결과는 Table 2에 제시 하였다.

\section{순음청력검사}

임피던스 청력검사를 통하여 대상자의 중이 상태가 정상인 지 평가하고, 순음청력검사를 통하여 $125 \mathrm{~Hz}$ 부터 8,000 Hz까 지의 각 주파수별 기도 및 골도 청력 역치를 측정하였으며, 6 분
Table 2. Descriptive statistics for hearing-related variables

\begin{tabular}{lc}
\hline \multicolumn{1}{c}{ Hearing-related variables } & Mean (SD) \\
\hline Better-ear PTA (dB HL) & $57.86(9.45)$ \\
Daily HA use (hours) & $8.47(3.85)$ \\
Sentence-in-noise recognition scores (\%) & $61.95(25.40)$ \\
K-HHIE & $43.39(26.97)$ \\
\hline
\end{tabular}

SD: standard deviation, PTA: pure-tone threshold average, HA: hearing aid, K-HHIE: Korean version of hearing handicap inventory for the elderly

법 계산을 적용하여 양측 귀의 평균 청력 역치를 구하였다.

\section{소음 상황에서의 문장인지도검사}

한국어음청력검사(Korean Speech Audiometry) (Lee et al., 2010)의 일반용 한국표준문장표를 사용하여 소음 상황에서의 문장인지도검사를 실시하였다. 방음실의 사운드필드에서 피검 자의 쾌적 수준에서 검사자가 육성으로 목표 문장을 제시하였 다. 배경 소음으로는 어음잡음을 제시하였으며, 고정된 신호 대 잡음비(signal-to-noise ratio, SNR), 즉 $5 \mathrm{~dB} \mathrm{SNR}$ 에서 검사를 시행하였고, 스피커는 피검자로부터 정면에서 $1 \mathrm{~m}$ 거리에 위치 시켰다. 본 연구와 동일하게 어음잡음하에서 한국표준문장표 를 사용하여 정상 성인의 문장인지도를 측정한 선행연구에 따 르면, 정상 성인의 경우 $\mathrm{SNR} 0 \mathrm{~dB}$ 이상에서 $80 \%$ 이상의 문장 인지도를 나타내었다(Choi, 2009). 이와 더불어 감각신경성 난 청 그룹은 정상 청력 그룹에 비해 소음 상황에서 평균 $4 \mathrm{~dB}$ 이 상 많은 SNR을 필요로 한다는 선행연구(Han et al., 2007) 결 과를 고려하여 본 연구에서는 $5 \mathrm{~dB} \mathrm{SNR}$ 을 적용해 문장인지도 검사를 시행하였다. 검사자는 피검자에게 스피커를 통해 제시 되는 문장을 끝까지 잘 듣고 따라 말하되, 전체 문장을 다 듣지 못했다 하더라도 들은 단어가 있을 경우 모두 말하도록 지시하 였다. 문장표를 구성하는 40개의 핵심 어휘 중 피검자가 정확하 게 따라 말한 개수를 백분율로 계산하여 소음 상황에서의 문 장인지도를 측정하였다.

\section{주관적 청력장애검사}

한국어판 고령자 청력장애검사(Korean version of hearing handicap inventory for the elderly, K-HHIE) (Park et al., 2011) 를 실시하여 피검자가 일상생활에서 주관적으로 느끼는 듣기 어 려움을 평가하였다. $\mathrm{K}-\mathrm{HHIE}$ 는 노년층의 청력 손실로 인한 주 관적 장애 정도를 정량화하는 도구로써 임상에서의 유용성이 확인된 자가 보고 설문검사이다(Park et al., 2011). K-HHIE는 난청으로 인한 태도 및 감정적 반응을 묻는 정서적 영역의 문 항 13 개와 난청으로 인해 사회 활동 시 겪게 되는 어려움을 묻 는 사회적/상황적 영역의 문항 12 개, 총 25 개 문항으로 구성되어 있다. 피검자는 각 문항에 대하여 “예”, “가끔”, "아니오”로 응답 
하며, 각각의 응답은 4점, 2점, 0 점으로 측정되어 항목별 점수의 합(총점 100점)으로 난청으로 인한 주관적 장애 정도를 파악하 게 된다. 총점이 44점 이상인 경우 심각한 듣기 어려움이 있는 것으로 해석하며, 18 점 이상 42 점 이하인 경우 경중도의 어려 움, 16 점 이하인 경우에는 자각하는 듣기 어려움이 거의 없는 것으로 해석할 수 있다.

\section{인지기능 평가}

본 연구에서는 전반적 인지능력, 정보처리속도, 집행기능, 의 미기억을 하위인지 영역으로 선정하여 평가를 시행하였다( $\left(\mathrm{Ta}^{-}\right.$ ble 3). 본 연구에서 ‘의미기억'의 하위검사로 분류한 의미유창성 검사의 경우, 집행기능, 어휘 인출, 의미지식 등 다양한 인지적 요소들이 관여하는 검사로 알려져 있으나(Shao et al., 2014), 본 연구에서는 McDermott \& Ebmeier(2009)의 메타 분석에 사용된 분류 방식에 따라 의미기억의 하위검사로 포함시켰다.

\section{전반적 인지능력}

난청 노인의 전반적인 인지능력을 평가하기 위하여 K-MMSE 를 시행하였다. K-MMSE는 임상에서 가장 많이 사용되는 인 지기능 선별검사로서 5 10분 정도의 짧은 시간 내 다양한 인지 적 요소들에 대한 선별적 평가가 가능하다. 총점 30점으로 시 간 지남력(5점), 장소 지남력(5점), 기억 등록(3점), 주의 집중 및 계산(5점), 기억 회상(3점), 언어(8점) 및 시공간 구성(1점)으로 이루어져 있으며, 연령 및 교육 수준에 따른 규준이 마련되어 있다(Kang, 2006).

의미기억

난청 노인의 의미기억을 평가하기 위하여 의미 범주의 단어 유창성 과제인 동물 이름대기 과제를 시행하였다. 피검자는 제 한된 시간(1분) 동안 ‘동물’이라는 의미적 범주에 해당하는 단어
를 최대한 많이 산출하게 된다(Kang et al., 2000). 일반적으로 1 분 동안 산출한 총 단어 수를 세어 수행력을 평가하는데, 이때 범주에 속하지 않는 단어나 고유명사 등은 정반응에서 제외하 며, 반복하여 산출한 단어는 한 번만 정반응으로 인정한다.

\section{정보처리속도}

난청 노인의 정보처리속도를 평가하기 위하여 한국판 노인용 기호잇기검사(Korean version of trail making test for the elderly, K-TMT-E) (Yi et al., 2007)의 A형 과제를 시행하였다. K-TMT-E는 A형과 B형의 두 가지 과제로 구성되는데, $\mathrm{A}$ 형은 피검자로 하여금 제한된 시간(300초) 동안 1 부터 15 까지의 숫 자를 순서대로 잇게 하여 피검자가 선 잇기를 완성할 때까지의 반응 시간을 측정한다. A형 반응 시간은 인지 영역 가운데 주 로 정보처리속도의 지표로 여겨진다(McDermott \& Ebmeier, 2009; Park et al., 2007).

집행기능

난청 노인의 집행기능을 평가하기 위하여 K-TMT-E의 B형 과 한국판 스트룹 검사(Korean version of color word stroop test, K-CWST) (Lee et al., 2000)를 시행하였다. K-TMT-E의 $\mathrm{B}$ 형은 $\mathrm{A}$ 형과 달리 숫자와 글자(요일)를 번갈아 가면서 교대로 잇게 하는데, 제한 시간(300초) 전에 완성하면 검사지에 '성공' 으로 표시하고 반응 시간과 오류 수를 기록하며, 제한 시간 내 성공하지 못하면 300초에서 수행을 중지시키고 검사지에 '실패' 로 표시하고 반응 시간은 300 초로 기록한다. 다음으로 $\mathrm{K}-$ CWST는 글자읽기 및 색깔읽기 과제로 구성되는데, 두 과제 모 두 피검자로 하여금 제한 시간(120초) 내 112 개의 자극 단어를 읽도록 한다. 두 과제 모두에서 자극 단어들은 글자가 적혀진 색깔과 글자의 뜻이 서로 일치되지 않는 문항들로 이루어져 있 는데(예: ‘노랑’이라는 글자가 검정색 잉크로 적혀 있음), 글자읽

Table 3. Descriptive statistics for neuropsychological test results subsumed in specific cognitive domains*

\begin{tabular}{llc}
\hline Cognitive domain & \multicolumn{1}{c}{ Neuropsychological tests } & Mean (SD) \\
\hline General cognition & K-MMSE & $27.95(1.29)$ \\
Semantic memory & Semantic fluency test & $13.08(3.61)$ \\
Processing speed & K-TMT-E part A: reaction time (sec) & $27.34(9.13)$ \\
Executive function & K-TMT-E part B: reaction time (sec) & $53.00(27.06)$ \\
& K-TMT-E part B: number of errors & $0.69(0.82)$ \\
& K-CWST word reading: number of correct responses & $109.65(6.79)$ \\
& K-CWST word reading: reaction time (sec) & $84.91(23.17)$ \\
& K-CWST color reading: number of correct responses & $80.52(22.80)$ \\
& K-CWST color reading: reaction time (sec) & $119.08(3.20)$ \\
& K-CWST: interference score & $0.71(0.19)$ \\
\hline
\end{tabular}

*We used the categorization system suggested by McDermott \& Ebmeier (2009). SD: standard deviation, K-MMSE: Korean-mini mental state examination, K-TMT-E: Korean version of trail making test for the elderly, K-CWST: Korean version of color word stroop test 
기 과제에서는 색깔 정보는 무시하고 글자를 읽어야 하는 반면 색깔읽기 과제에서는 글자 정보는 무시하고 글자가 적혀진 색 깔을 읽어야 한다. 두 과제 모두에서 제한 시간 내 112 개의 자 극을 다 읽지 못하면 검사를 중지하고 120 초가 경과했을 때까 지의 정반응 수와 오반응 수를 기록한다. 본 연구에서는 $\mathrm{K}-$ CWST의 측정치로서 반응 시간 및 정반응 수를 측정하였는데, 반응 시간은 길수록 수행력이 낮다는 것을 의미하며, 정반응 수는 많을수록 수행력이 높음을 의미한다. 더불어 간섭점수 (interference score)를 산출하였는데, 이는 색깔읽기 과제의 항 목당 반응 시간에서 글자읽기 과제의 항목당 반응 시간을 뺀 점수로서, 간섭 점수가 높을수록 관련 없는 정보에 대한 억제 (inhibition) 능력이 저하됨을 의미한다.

\section{연구 절차}

일차적으로 대상자가 선정기준에 부합하는지 선별하기 위하 여 기초건강선별설문지를 시행하였으며, 연령 및 성별, 교육연 수, 직업, 손잡이 등의 기본 정보를 수집하기 위한 면담이 이루 어졌다. 다음으로 청력검사실의 방음실에서 순음청력검사 및 어음청력검사, 임피던스 청력검사를 통해 대상자의 청력을 확 인하고, 그 외 보청기 사용 여부, 일 평균 보청기 착용 시간 등 의 정보를 확인하였다. 선정기준에 부합하는 경우에 한해 $\mathrm{K}-$ $\mathrm{MMSE}$ 를 비롯한 인지기능 평가와 SGDS 및 $\mathrm{K}-\mathrm{HHIE}$ 설문검 사가 이루어졌다. 모든 검사는 조용한 방에서 검사자와 피험자 간 일대일 방식으로 이루어졌으며, 피험자는 반응지에 직접 응 답하거나, 피험자가 구두로 응답하는 과제인 경우에는 검사자 가 피험자의 반응을 실시간으로 기록하는 동시에 보이스 레코 더로 녹음하였다.

\section{통계 분석}

자료의 통계처리는 SPSS 25.0 version (IBM Corp., Armonk, $\mathrm{NY}, \mathrm{USA}$ )을 사용하였다. 첫째, 난청 노년층을 대상으로 인구 통계학적 변인, 청력 및 인지 관련 변인 가운데 난청 노인의 우 울과 상관성이 있는 변인이 무엇인지 알아보기 위하여 피어슨 상관계수(Pearson correlation coefficient) 분석을 시행하였다. 둘째, 유의한 상관을 나타낸 변인들 가운데 난청 노인의 우울 에 가장 크게 영향을 미치는 변인이 무엇인지 알아보기 위하여 단계적 다중회귀분석(stepwise multiple linear regression)을 시행하였다. 통계학적 유의수준은 0.05 미만으로 설정하였다.

\section{RESULTS}

\section{난청 노인의 우울과 인구통계학적 변인 간 상관관계}

난청 노인의 우울과 인구통계학적 변인(연령, 성별, 교육연수)
간 상관성을 알아보기 위해 상관분석을 실시하였다. 그 결과 난 청 노인의 우울을 나타내는 SGDS 점수와 연령 $(\mathrm{r}=0.168, p=$ 0.444), 성별( $\mathrm{r}=0.019, p=0.932)$, 교육연수( $\mathrm{r}=-0.216, p=$ $0.321)$ 간 유의한 상관성이 나타나지 않았다. 난청 노인의 우울과 인구통계학적 변인 간 상관분석 결과는 Table 4에 제시하였다.

\section{난청 노인의 우울과 청력 관련 변인 간 상관관계}

난청 노인의 우울과 청력 관련 변인(평균순음역치, 평균 보청 기 착용 시간, 소음 상황에서의 문장인지도, $\mathrm{K}-\mathrm{HHIE}$ 점수) 간 상관성을 알아보기 위해 상관분석을 실시하였다. 그 결과 난청 노인의 우울을 나타내는 SGDS 점수와 좋은 쪽 귀의 평균순음 역치 간에 유의한 정적 상관이 나타났으며 $(\mathrm{r}=0.564, p<0.01)$, $\mathrm{SGDS}$ 점수와 $\mathrm{K}-\mathrm{HHIE}$ 점수 간에도 유의한 정적 상관을 확인 하였다 $(\mathrm{r}=0.465, p<0.05)$. 또한 난청 노인의 SGDS 점수와 소음 상황에서의 문장인지도 간에는 유의한 부적 상관이 나타 났다 $(\mathrm{r}=-0.528, p<0.05)$. 반면, SGDS 점수와 평균 보청기 착 용 시간 간에는 유의한 상관성이 나타나지 않았다 $(\mathrm{r}=-0.123$, $p=0.576)$. 난청 노인의 우울과 청력 변인 간 상관분석 결과는 Table 5에 제시하였다.

\section{난청 노인의 우울과 인지 관련 변인 간 상관관계}

난청 노인의 우울과 인지 관련 변인(전반적 인지능력, 의미기억, 정보처리속도, 집행기능) 간 상관성을 알아보기 위해 상관 분석을 실시하였다. 그 결과 난청 노인의 우울을 나타내는 SGDS 점수와 집행기능을 반영하는 $\mathrm{K}-\mathrm{TMT}-\mathrm{E}$ 의 B형 반응 시간 간 유의한 정 적 상관이 나타났으며 $(\mathrm{r}=0.582, p<0.01)$, 더불어 정보처리속 도의 지표가 되는 $\mathrm{K}-\mathrm{TMT}-\mathrm{E}$ 의 $\mathrm{A}$ 형 반응 시간 간 유의한 정적 상관이 확인되었다 $(\mathrm{r}=0.466, p<0.05)$. 그 외 인지기능 변인들

Table 4. Correlation coefficients of the short version of geriatric depression scale scores with demographic variables

\begin{tabular}{ccc}
\hline Demographic variables & $\mathrm{r}$ & $p$-value \\
\hline Age & 0.168 & 0.444 \\
Gender & 0.019 & 0.932 \\
Education level & -0.216 & 0.321 \\
\hline
\end{tabular}

Table 5. Correlation coefficients of the short version of geriatric depression scale scores with hearing-related variables

\begin{tabular}{lcc}
\hline \multicolumn{1}{c}{ Hearing-related variables } & $\mathrm{r}$ & $p$-value \\
\hline Better-ear PTA & 0.564 & $0.005^{\dagger}$ \\
Daily HA use & -0.123 & 0.576 \\
Sentence-in-noise recognition scores & -0.528 & $0.010^{*}$ \\
K-HHIE & 0.465 & $0.025^{*}$ \\
\hline
\end{tabular}

${ }^{*} p<0.05,{ }^{\dagger} p<0.01$. PTA: pure-tone threshold average, HA: hearing aid, K-HHIE: Korean version of hearing handicap inventory for the elderly 
Table 6. Correlation coefficients of the short version of geriatric depression scale scores with neuropsychological variables

\begin{tabular}{llcc}
\hline Cognitive domain & \multicolumn{1}{c}{ Neuropsychological variables } & $\mathrm{r}$ & $p$-value \\
\hline General cognition & K-MMSE & -0.140 & 0.524 \\
Semantic memory & Semantic fluency test & 0.069 & 0.754 \\
Processing speed & K-TMT-E part A: reaction time (sec) & 0.466 & $0.025^{*}$ \\
Executive function & K-TMT-E part B: reaction time (sec) & 0.582 & $0.004^{\dagger}$ \\
& K-TMT-E part B: number of errors & 0.101 & 0.645 \\
& K-CWST word reading: number of correct responses & -0.360 & 0.092 \\
& K-CWST word reading: reaction time (sec) & 0.394 & 0.063 \\
& K-CWST color reading: number of correct responses & -0.222 & 0.309 \\
& K-CWST color reading: reaction time (sec) & 0.132 & 0.547 \\
& K-CWST: interference score & 0.388 & 0.067 \\
\hline
\end{tabular}

${ }^{*} p<0.05,{ }^{\dagger} p<0.01$. K-MMSE: Korean-mini mental state examination, K-TMT-E: Korean version of trail making test for the elderly, KCWST: Korean version of color word stroop test

간에는 유의한 상관성이 나타나지 않았다. 난청 노인의 우울과 인지 관련 변인 간 상관분석 결과는 Table 6에 제시하였다.

\section{난청 노인의 우울에 영향을 미치는 변인}

난청 노인의 우울에 영향을 미치는 변인이 무엇인지 알아보 기 위하여 피어슨 상관분석 시에 유의한 상관이 확인된 총 5 개 변인(평균순음역치, 소음 상황에서의 문장인지도, $\mathrm{K}-\mathrm{HHIE}$ 점 수, K-TMT-E A형 및 B형 반응 시간)을 독립변수로 하고 SGDS 점수를 종속변수로 하여 단계적 다중회귀분석을 실시하였다. 그 결과 최종 회귀모형에서 총 2 개 변인, 즉, 평균순음역치 $(\beta=$ $0.383, p<0.05)$ 및 $\mathrm{K}-\mathrm{TMT}-\mathrm{E}$ 의 $\mathrm{B}$ 형 반응 시간 $(\beta=0.415, p<$ $0.05)$ 이 난청 노인의 우울에 유의한 영향을 미치는 것으로 나타 났다. 본 회귀모형은 통계적으로 유의하며 $(\mathrm{F}=8.427, p<0.01)$, 결정계수 $\left(R^{2}\right)$ 는 0.457 , 수정된 결정계수(adjusted $\left.R^{2}\right)$ 는 0.403 으로서 본 회귀모형은 난청 노인의 우울감에 대하여 약 $40.3 \%$ 의 설명력을 갖는 것으로 나타났다. 난청 노인의 우울과 관련 변인들 간 다중회귀분석 결과는 Table 7에 제시하였다.

\section{DISCUSSIONS}

본 연구에서는 인구통계학적 변인, 청력 관련 변인, 인지 관 련 변인 가운데 난청 노인의 우울과 상관이 있는 변인이 무엇인 지 살펴보고 난청 노인의 우울과 유의한 상관이 나타난 변인들 가운데 우울에 영향을 미치는 주요 변인이 무엇인지 밝히고자 하였다. 연구 결과 청력 관련 변인 가운데 3개 변인, 즉 평균순 음역치, 소음 상황에서의 문장인지도, 주관적 청력장애 정도가 난청 노인의 우울과 유의한 상관이 있었으며, 인지 관련 변인 가운데서는 집행기능을 반영하는 K-TMT-E의 B형 반응 시간 및 정보처리속도의 지표가 되는 K-TMT-E의 A형 반응 시간이 난청 노인의 우울과 유의한 상관을 나타내었다. 유의한 상관이
Table 7. Results of stepwise linear regression with the short version of geriatric depression scale scores as the dependent variable

\begin{tabular}{lccc}
\hline \multicolumn{1}{c}{ Variables } & $\mathrm{B}$ & $\beta$ & $p$-value \\
\hline Better-ear PTA & 0.180 & 0.383 & $0.049^{*}$ \\
K-TMT-E part B: reaction time & 0.068 & 0.415 & $0.034^{*}$ \\
$\mathrm{R}^{2}$ & & 0.457 & \\
Adjusted R & & 0.403 & \\
\hline
\end{tabular}

${ }^{*} p<0.05$. PTA: pure-tone threshold average, K-TMT-E: Korean version of trail making test for the elderly

나타난 총 5 개 변인을 사용하여 다중회귀분석을 실시한 결과, 최종 회귀모형에서는 평균순음역치 및 K-TMT-E B형 반응 시 간이 난청 노인의 우울에 영향을 미치는 주요 요인으로 확인되 었다. 본 연구 결과를 토대로 다음의 세 가지 측면에서 논의점 을 제시해보고자 한다.

청력 관련 변인들과 관련하여 첫째, 난청의 정도와 우울 간의 상관은 대부분의 선행연구들과 일치하는 결과이다. Chun et al. (2005)은 65세 이상 노인을 대상으로 평균청력역치가 상승할 수록 우울 점수가 증가하는 양상을 밝혔는데, 정상 청력, 경도 난청, 중도 난청, 중고도 난청의 순으로 우울 점수가 점차 증가 하는 것이 확인되었다. Kim et al.(2015)의 연구에서도 순음청력 검사에 의한 난청의 정도와 우울의 관계를 측정하였는데 청력 의 손실이 심할수록 우울 점수가 증가하는 것을 확인하였으며 특히, 시각장애에 비해 청각장애가 노인 우울에 미치는 영향이 더 크다는 점을 보고하였다. 둘째, 본 연구에서는 평균순음역치 뿐만 아니라 K-HHIE 점수, 즉 난청 노인이 주관적으로 보고 한 청각장애 정도와 우울 간에도 유의한 정적 상관이 나타났 다. K-HHIE는 노년층의 청력 손실로 인한 주관적 장애 정도 를 정량화하는 도구로써, 난청으로 인한 태도 및 감정적 반응 을 묻는 정서적 영역의 문항과 난청으로 인해 사회 활동 시 겪 게 되는 어려움을 묻는 사회적/상황적 영역의 문항들로 구성되 어 있다(Park et al., 2011). 즉, 본 연구의 결과는 동일한 정도의 
청력 손실을 나타내는 노인이라 하더라도 일상생활에서 느끼 고 경험하는 주관적 장애 정도가 큰 노인일수록 더 많은 우울 감을 나타낼 가능성이 있음을 시사한다. 난청 노인의 경우 우 울 요소 가운데 특히 불안(insecurity)이 일상생활에서 경험하 는 주관적 장애 정도와 관련이 높은 것으로 밝혀진 바 있다 (Eriksson-Mangold \& Carlsson, 1991). 본 연구결과는 초기 노인성 난청자를 대상으로 우울 정도가 높을수록 K-HHIE 점 수가 높음을 보고한 선행연구(Lee et al., 2019)와도 일맥상통 한다. 셋째, 본 연구에서는 청력 관련 변인들 가운데 난청 노인 의 평균순음역치 및 주관적 장애 정도와 더불어 소음 상황에 서의 문장인지도 점수와 우울 간에도 유의한 부적 상관을 확인 하였다. 노인성 난청의 주요 특징은 중추청각처리능력의 결함으 로 인해 어음 변별력이 저하되며, 특히 소음 환경에서의 듣기에 어려움을 나타낸다는 것이다(Gates \& Mills, 2005). 노인의 경우 청력이 정상이라 할지라도 청년에 비해 말소리 지각 능력이 뚜 렷하게 저하되는데, 이는 청력 이외의 인지적 요인들이 말소리 지각에 영향을 미치기 때문이다(Pichora-Fuller et al., 1995). 노화에 따른 인지능력의 감퇴는 소음 상황에서의 듣기에 관여 하는 하향식(bottom-up) 말 지각 처리의 효율성을 저하시키는 데, 즉 선행지식이나 문맥적 단서를 활용하여 소음으로 인해 왜 곡되거나 소실된 정보를 추론하는 동시에 정확히 들은 정보는 기억해야 하는 동시적 인지 처리 과정이 효율적으로 이루어지 지 못하게 되는 것이다(Pichora-Fuller et al., 1995). 동일한 수 준의 난청을 보이는 노년층 내에서도 청자의 인지능력이 관여 하는 정도가 높아지는 소음 속 듣기 상황들, 예를 들어 사교모 임에 참석했을 때나 시끄러운 식당에서의 듣기 어려움 등을 호 소한 집단이 사회적 측면에서뿐만 아니라 정서적 측면에서의 주 관적 장애 정도를 더 많이 보고한 바 있다(Lee, 2018). 또한 초기 노인성 난청을 나타내는 경도인지장애 노년층을 대상으로 한 선행연구에서도 소음 상황에서의 문장인지도 점수가 낮을수록 더 많은 정서적, 사회적 측면에서의 듣기 어려움을 호소하는 것 으로 나타났다(Lee et al., 2019). 이러한 선행연구 결과들은 소 음 상황에서의 문장인지도 점수와 우울 간 부적 상관을 확인 한 본 연구의 결과와도 일맥상통한다고 볼 수 있다. 실제 난청 노인들이 겪게 되는 대부분의 의사소통 상황이 조용한 상황보 다는 주변에 배경 소음이 있거나 혹은 여러 사람들이 동시에 대 화를 주고받는 경우인 점을 미루어 볼 때 소음 상황에서의 말소 리 지각능력이 저하될수록 여러 사람들이 함께 모이는 사교모 임이나 사회적 활동에의 참여를 기피하게 될 것임은 분명하다. 이는 대인관계 기피 및 사회적 고립으로 이어져 우울과 같은 정 신과적 문제들을 야기할 수 있다(Strawbridge et al., 2000). 넷째, 청력 관련 변인들 가운데 일 평균 보청기 착용 시간과 우울 간 에는 유의한 상관이 나타나지 않았다. 이에 대해서는 보청기 착
용 시간뿐만 아니라 착용 중인 보청기가 사용자의 청력 손실 정 도나 유형에 맞게 얼마나 최적의 상태로 피팅되어 있는가 등이 중요한 변수가 되기 때문에 우울과 보청기 착용 시간 간에 유의 한 상관이 나타나지 않았을 가능성이 있다. 이는 추후 연구를 통한 재확인이 필요한 부분이라고 하겠다.

다음으로 인지 관련 변인과 우울 간 상관을 살펴보면, 정보처 리속도를 반영하는 K-TMT-E의 A형 반응 시간 및 집행기능을 반영하는 K-TMT-E의 B형 반응 시간과 난청 노인의 우울 간 유 의한 상관이 확인되었다. 일반 노인 집단에서 인지기능과 우울 간 관련성은 이미 잘 알려진 사실이나(McDermott \& Ebmeier, 2009), 본 연구를 통해 난청 노인 집단에서의 두 요인 간 관련 성은 새롭게 확인되었다. K-TMT-E는 A형과 B형의 두 가지 과제로 구성되는데 $\mathrm{A}$ 형은 피검자로 하여금 1 부터 15 까지의 숫 자를 순서대로 잇게 하는 반면, B형은 숫자와 글자(요일)를 번 갈아 가면서 교대로 잇게 하여 피검자가 선 잇기를 완성할 때까 지 걸린 시간을 측정한다. 이때 $\mathrm{A}$ 형 반응 시간은 주로 정보처리 속도(information processing speed)의 지표가 되며 B형 반응 시간은 주의력 전환(set shifting) 및 인지적 유연성(cognitive flexibility)의 요소를 포함하는 집행기능을 측정하는 지표가 된 다(McDermott \& Ebmeier, 2009; Park et al., 2007). 즉, 본 연 구를 통해 난청 노인에서 정보처리속도 및 집행기능(특히, 인지 적 유연성)이 저하될수록 더 많은 우울 증상을 나타낼 경향성 이 있음이 확인되었다. 본 연구에 포함된 인지 관련 변인 가운데 의미기억은 난청 노인의 우울과 상관이 없는 것으로 나타났는 데, 이는 집행기능 및 정보처리속도가 우울의 중증도와 관련 있 는 반면 의미기억과는 관련성이 없음을 확인한 선행연구 (Cataldo et al., 2005) 결과와 일치한다.

우울 정도와 인지기능 간 관련성에 대한 메타분석 연구에 따 르면 우울의 중증도는 인지기능 저하와 관련되는데 그 관련성 의 정도는 인지 영역 간 차이가 있었다(McDermott \& Ebmei$\mathrm{er}, 2009)$, 즉, 집행기능(-0.32), 일화기억(-0.31), 정보처리속도 $(-0.16)$ 순으로 높은 효과 크기를 나타냈고 시공간기억 및 의미 기억과 우울 간에는 유의한 상관이 확인되지 않았다. 이는 난 청 노인을 대상으로 한 본 연구의 결과와도 일치하는데, 집행기 능이나 정보처리속도의 저하가 난청 노인의 우울과 어떠한 관 련성이 있는지에 대해서는 여러 가지 측면에서의 해석이 가능 하다. Wayne \& Johnsrude(2015)에 따르면 노화로 인한 감각기 능의 저하는 '지각적 어려움(perceptual difficulty)'을 야기하며, 이러한 지각적 어려움으로 인해 우울증 등의 정신적 문제들이 발생하게 된다. 이때 노인의 '지각적 어려움'을 높이는 주요 요인 이 집행기능 결함이나 정보처리속도의 저하이다(D'Ausilio et al., 2012; Lee et al., 2018). 예컨대 소음 상황에서 말소리를 올 바르게 지각하기 위해서는 목표와 무관한 자극에 대한 반응은 
억제하고 목표 자극에 대해서만 선택적으로 주의 집중하는 능 력이 필수적이며, 여러 명의 사람들과 대화 시에는 빠르게 주의 력을 전환하거나 다양한 주제나 상황에 적응할 수 있는 인지적 유연성이 요구된다(D’Ausilio et al., 2012; Lee et al., 2018). 선택 적 주의력, 반응 억제, 인지적 유연성, 전환 능력 등은 모두 집행 기능을 이루고 있는 핵심 요소들에 해당한다(Diamond, 2013). 이 러한 측면에서 집행기능이나 정보처리속도 등의 저하는 말소리 지각의 어려움을 심화시키고 이는 일상생활에서의 의사소통 단절을 초래하여 사회적, 정서적 고립을 야기함으로써 우울 등 의 정신적 문제를 유발할 수 있다. 단, 본 연구에서는 집행기능 측정치 가운데 $\mathrm{K}-\mathrm{CWST}$ 검사 측정치들은 난청 노인의 우울과 상관이 없는 것으로 나타났는데 이는 $\mathrm{K}-\mathrm{CWST}$ 가 집행기능을 평가하는 동시에 피검자 개인의 읽기능력이 개입되는 정도가 큰 검사이기 때문일 가능성이 있다(Scarpina \& Tagini, 2017). 본 연 구에서는 학력이 인지검사에 미치는 영향을 최소화하기 위하여 교육연수를 최소 6년 이상으로 제한하였으나, 그럼에도 불구하 고 K-CWST 측정치와 우울 점수 간 상관분석 시에 난청 노인 개개인의 읽기능력이 혼란변수로 작용했을 가능성이 있겠다. 끝으로 본 연구에 포함된 인지 관련 변인들 가운데 전반적 인 지기능(K-MMSE 점수) 역시 우울과 유의한 상관이 나타나지 않았는데, 이는 본 연구가 $\mathrm{K}-\mathrm{MMSE}$ 를 통하여 정상 인지기능 을 보이는 난청 노인만을 대상으로 하였기 때문에 대상자 간 $\mathrm{K}-\mathrm{MMSE}$ 점수의 편차가 크지 않아서일 가능성이 있으며, 추 후 전체 난청 노인을 대상으로 $\mathrm{K}-\mathrm{MMSE}$ 점수와 우울 간 관련 성을 살펴볼 필요가 있겠다.

본 연구의 경우 인구통계학적 변인들, 즉, 연령, 성별, 교육연 수와 우울 간에는 유의한 상관이 나타나지 않았다. 정상 노인 을 대상으로 한 연구(Glaesmer et al., 2011)에서 연령, 성별 및 교육 수준 등이 우울 증상에 영향을 미치는 주요 요인으로 나 타난 것과는 비교되는 결과이다. 다양한 연령층을 포함한 선행 연구(Glaesmer et al., 2011)와 달리 본 연구의 경우, 난청 노인 대상자 수가 총 23명으로 표본 크기가 작을 뿐만 아니라 총 23 명 중 15 명(약 $65 \%$ )이 75 세 이상의 고령에 해당하여 생활 연령 자체보다는 개인의 건강 상태나 경제적 수준 등의 기타 요인이 우울 증상에 영향을 미칠 가능성이 높다. 또한 난청 노인의 일 상생활 핸디캡을 조사한 선행연구에 따르면, 교육연수가 12년 이하인 난청 노인의 경우 12 년 이상인 집단에 비해 주관적 장애 정도를 덜 느끼는 것으로 보고된 바 있다(Wiley et al., 2000). 즉, 일정 수준 이상으로 교육 수준이 높으면 난청으로 인한 어 려움을 스스로 더 크게 자각한다는 것이다. 난청 노인이 일상 생활에서 경험하는 주관적 장애 정도와 우울 간 관련성이 있 음(Lee et al., 2019)을 고려해 볼 때, 본 연구에 포함된 난청 노 인의 경우 한 명을 제외하고 교육연수가 모두 6년 이상 12 년 이
하에 해당하여 교육 수준이 우울 증상에 미치는 영향이 크지 않을 가능성이 있다. 정상 노인과 달리 이미 난청이라는 질환 을 않고 있는 만큼, 연령이나 교육 수준보다는 질환의 중증도, 즉 청력 손실의 정도가 우울에 더 크게 영향을 미쳤을 수 있을 것으로 본다.

난청 노인의 우울과 유의한 상관이 확인된 5 개 변인들 가운 데 최종 회귀모형에서는 평균순음역치와 K-TMT-E의 B형 반 응 시간이 난청 노인의 우울에 영향을 미치는 주요 요인으로 나타났다. 즉, 다른 요인들이 통제된 상태에서 청력역치가 높을 수록, 그리고 K-TMT-E의 B형 반응 시간이 길수록, 즉 집행기 능 요소 가운데 인지적 유연성이 저하될수록 난청 노인은 더 많 은 우울감을 호소하는 것으로 해석할 수 있다. 난청과 우울 간 관련성을 설명하고자 하는 여러 가지 다양한 시도가 이루어지 고 있지만 난청으로 인한 의사소통 실패가 사회적 고립이나 좌 절을 유발하여 노인 우울을 증가시킨다고 보는 것이 일반적이 다(Huang et al., 2010; Mener et al., 2013; Strawbridge et al., 2000). 이러한 측면에서 청력 손실 정도 및 집행기능, 특히, 인지 적 유연성은 난청 노인의 의사소통 질을 좌우하는 주요 요인이 되며, 이를 통해 난청 노인의 우울에도 영향을 미치게 된다고 보는 것이 타당할 것이다.

본 연구결과를 통해 난청 노인은 청력 손실 정도가 심할수 록, 그리고 집행기능이 저하될수록 우울을 더 많이 나타낼 가 능성이 있음을 확인하였다. 이는 난청 노인의 중재 시에 고려될 수 있는데, 즉, 적절한 보장구 착용을 통한 청력 손실 보상과 더불어 난청이 더 심화되지 않게 하기 위한 예방적 조치가 시행 될 필요가 있다. 예컨대 지역사회 거주 노인을 대상으로 난청의 위험 요인을 알리고 이에 대한 노출을 최소화하기 위한 교육을 시행하거나 청각장애 진단 절차 및 보장구 지원 절차에 대한 안내 등이 정기적으로 이루어질 필요가 있을 것이다. 또한 청능 재활과 더불어 난청 노인의 인지처리속도나 인지적 유연성을 높이는 데 목표를 둔 포괄적 측면에서의 청각-인지재활이 이루 어진다면 난청 노인에서 우울과 같은 심리정서적 문제를 완화 하는 데 도움이 될 수 있을 것이다. 또한 심화된 우울증의 경우 에는 관련 전문가로의 평가 의뢰 및 심리치료나 약물치료의 병 행 등이 고려되어야 할 것이다. 노인의 우울은 그 자체로도 사 회적, 경제적 부담을 증가시킬 뿐 아니라 노인 자살을 야기하는 주요 원인이 된다는 점에서 심각한 문제로 여겨지고 있다. 또한 우울은 치매와 같은 인지장애 발생에 대한 위험인자가 되기 때 문에 적극적 중재가 필요한 영역임에 틀림없다. 이에 따라 난청 노인의 심리정서적 특성을 이해하고자 하는 사회적 분위기 조 성과 더불어 실질적이고 체계적으로 사회적 지지를 제공할 수 있는 사회적 관계망의 토대가 마련되어야 할 것으로 본다.

끝으로 본 연구의 제한점과 후속연구에 대한 제언을 덧붙이 
고자 한다. 첫째, 본 연구에서는 인구통계학적 변인과 난청 노인 의 우울 간에는 유의한 상관이 나타나지 않았다. 연령 및 성별 과 더불어 노인의 사회경제적 지위가 노년층의 우울에 영향을 미친다는 선행연구 결과들을 고려할 때(Glaesmer et al., 2011), 추후 연구에서는 표본 크기를 늘려 난청 노인에서 인구통계학 적 변인 및 사회경제적 변인이 우울에 미치는 영향을 재확인할 필요가 있겠다. 둘째, 본 연구에서는 인지 관련 변인들로 전반 적 인지기능, 집행기능, 정보처리속도, 의미기억을 포함시켰다. 우울은 전전두피질(prefrontal cortex)뿐만 아니라 내측두엽에 위치한 해마(hippocampus)의 구조 및 기능을 변화시킨다는 점 (Bremner et al., 2004)을 고려해 볼 때, 추후 연구에서는 일화 기억(episodic memory) 및 시공간기억(visuo-spatial memory) 의 인지 영역을 추가적으로 포함하여 난청 노인의 우울과 인지 기능 결함 간 관련성을 종합적으로 분석할 필요가 있겠다. 셋째, 본 연구에서는 현재 시점에서 보청기를 착용하는 노인들만을 연구 대상에 포함시켰다. 보청기 착용 여부가 난청자의 우울에 영향을 미친다는 최근 연구들(Choi et al., 2016)을 고려하여 추 후 연구에서는 보청기 착용 여부가 난청 노인의 우울에 미치는 영향을 파악할 필요가 있을 것이다.

중심 단어 : 우울·노인·집행기능·난청·청력 역치.

\section{Ethical Statement}

This study was approved by the Institutional Review Board of Tongmyong University (IRB\# 201809-HR-001).

\section{Acknowledgments \\ N/A}

\section{Declaration of Conflicting Interests \\ There are no conflict of interests.}

\section{Funding \\ N/A}

\section{Author Contributions}

All authors contributed equally to this work. Y.L. designed and performed experiments, analyzed data, and wrote the paper; S.P. performed experiments in the clinic and provided critical revision; S.L. designed and performed experiments, analyzed data, wrote the paper, and provided statistical analysis and critical revision. Also, the authors discussed the results together and implications and commented on the manuscript at each stage.

\section{ORCID iDs}

Youngmee Lee Soo Jung Lee

https://orcid.org/0000-0003-1809-5944 https://orcid.org/0000-0003-0954-5181

\section{REFERENCES}

Bremner, J. D., Vythilingam, M., Vermetten, E., Vaccarino, V., \& Charney, D. S. (2004). Deficits in hippocampal and anterior cingulate functioning during verbal declarative memory encoding in midlife major de- pression. The American Journal of Psychiatry, 161(4), 637-645.

Byers, A. L. \& Yaffe, K. (2011). Depression and risk of developing dementia. Nature Reviews Neurology, 7(6), 323-331.

Cataldo, M. G., Nobile, M., Lorusso, M. L., Battaglia, M., \& Molteni, M. (2005). Impulsivity in depressed children and adolescents: A comparison between behavioral and neuropsychological data. Psychiatry Research, 136(2-3), 123-133.

Cho, M. J., Bae, J. N., Suh, G. H., Hahm, B. J., Kim, J. K., Lee, D. W., et al. (1999). Validation of geriatric depression scale, Korean version (GDS) in the assessment of DSM-III-R major depression. Journal of Korean Neuropsychiatric Association, 38(1), 48-63.

Choi, H. S. (2009). The effects of noise type and signal-to-noise ratio on sentence recognition performance. (Unpublished master's thesis). Hallym University, Chuncheon.

Choi, J. S., Betz, J., Li, L., Blake, C. R., Sung, Y. K., Contrera, K. J., et al. (2016). Association of using hearing aids or cochlear implants with changes in depressive symptoms in older adults. JAMA Otolaryngology-Head and Neck Surgery, 142(7), 652-657.

Chun, H. T., Cho, S. H., \& Cho, S. J. (2005). A study of geriatric depression propensity based on hearing loss of the old. Audiology, 1(1), 51-58.

D'Ausilio, A., Craighero, L., \& Fadiga, L. (2012). The contribution of the frontal lobe to the perception of speech. Journal of Neurolinguistics, 25(5), 328-335.

Diamond, A. (2013). Executive functions. Annual Review of Psychology, 64, 135-168.

Elderkin-Thompson, V., Hellemann, G., Pham, D., \& Kumar, A. (2009). Prefrontal brain morphology and executive function in healthy and depressed elderly. International Journal of Geriatric Psychiatry, 24(5), 459-468.

Eriksson-Mangold, M. \& Carlsson, S. G. (1991). Psychological and somatic distress in relation to perceived hearing disability, hearing handicap, and hearing measurements. Journal of Psychosomatic Research, 35(6), 729-740.

Gates, G. A. \& Mills, J. H. (2005). Presbycusis. The Lancet, 366(9491), 11111120.

Glaesmer, H., Riedel-Heller, S., Braehler, E., Spangenberg, L., \& Luppa, M. (2011). Age- and gender-specific prevalence and risk factors for depressive symptoms in the elderly: A population-based study. International Psychogeriatrics, 23(8), 1294-1300.

Han, S., Shin, J., Park, H., Koo, S., \& Lim, D. (2007). Comparison of HINT performances in subjects with SNHL and normal hearing. Audiology, 3(2), 161-163.

Huang, C. Q., Dong, B. R., Lu, Z. C., Yue, J. R., \& Liu, Q. X. (2010). Chronic diseases and risk for depression in old age: A meta-analysis of published literature. Ageing Research Reviews, 9(2), 131-141.

Kang, Y. W. (2006). A normative study of the Korean mini-mental state examination (K-MMSE) in the elderly. Korean Journal of Psychology: General, 25(2), 1-12.

Kang, Y. W., Chin, J. H., Na, D. L., Lee, J. H., \& Park, J. S. (2000). A normative study of the Korean version of controlled oral word association test (COWAT) in the elderly. Korean Journal of Clinical Psychology, 19(2), 385-392.

Kim, H. J., Kim, B. H., \& Kim, O. S. (2011). The effect of visual and hearing impairment on depression and cognitive function in communitydwelling elderly: The Korean longitudinal study of aging 2008. Korean Journal of Adult Nursing, 23(6), 584-594.

Kim, J. S. \& Lee, B. S. (2011). Hearing status in Korean adults according to the fourth Korea National Health and Nutrition Examination Survey 2009. Journal of Korean Public Health Nursing, 25(2), 197-208.

Kim, K. S., Shin, E. Y., \& Joo, S. H. (2015). The effects of vision and hearing function on the quality of life in the elderly. The Korean Journal of Vision Science, 17(4), 415-429.

Korea Centers for Disease Control and Prevention. (2012, August 30). Korea Health Statistics 2009: Korea National Health and Nutrition Examination Survey. KCDC. Retrieved from https://knhanes.cdc.go.kr/ 
knhanes/sub04/sub04_03.do?classType=7.

Lee, J. H., Jo, S. J., Kim, J. S., Jang, H. S., Lim, D. H., Lee, K. W., et al. (2010). Korean Speech Audiometry (KSA). Seoul: Hakjisa.

Lee, J. H., Kang, Y. W., \& Na, D. L. (2000). Efficiencies of stroop interference indexes in healthy older adults and dementia patients. Korean Journal of Clinical Psychology, 19(4), 807-818.

Lee, S. J. (2018). Effects of cognitive impairment on self-reported hearing handicap in older adults with early-stage presbycusis. Journal of the Korean Gerontological Society, 38(1), 1-14.

Lee, S. J., Kim, H., Kim, L. S., Kim, J. H., \& Park, K. W. (2019). Effects of frontal-executive dysfunction on self-perceived hearing handicap in the elderly with mild cognitive impairment. PloS One, 14(3), e0210014.

Lee, S. J., Park, K. W., Kim, L. S., \& Kim, H. (2018). Association between frontal-executive dysfunction and speech-in-noise perception deficits in mild cognitive impairment. Journal of Clinical Neurology, 14(4), 513-522.

McDermott, L. M. \& Ebmeier, K. P. (2009). A meta-analysis of depression severity and cognitive function. Journal of Affective Disorders, 119(13), 1-8.

Mener, D. J., Betz, J., Genther, D. J., Chen, D., \& Lin, F. R. (2013). Hearing loss and depression in older adults. Journal of the American Geriatrics Society, 61(9), 1627-1629.

Naismith, S. L., Hickie, I. B., Turner, K., Little, C. L., Winter, V., Ward, P. B., et al. (2003). Neuropsychological performance in patients with depression is associated with clinical, etiological and genetic risk factors. Journal of Clinical and Experimental Neuropsychology, 25(6), 866-877.

Park, J., Kang, Y., Yi, H., Kim, Y. J., Ma, H. I., \& Lee, B. C. (2007). Usefulness of the Korean trail making test for the elderly (K-TMT-e) in detecting the frontal lobe dysfunction. Dementia and Neurocognitive Disorders, 6(1), 12-17.

Park, S. N., Han. G. C., Cho, Y. S., Byun, J. Y., Shin, J. E., Chu, H. S., et al.
(2011). Standardization for a Korean version of hearing handicap inventory for the elderly. Korean Journal of Otorhinolaryngology-Head and Neck Surgery, 54, 828-834.

Pichora-Fuller, M. K., Schneider, B. A., \& Daneman, M. (1995). How young and old adults listen to and remember speech in noise. The Journal of the Acoustical Society of America, 97(1), 593-608.

Scarpina, F. \& Tagini, S. (2017). The stroop color and word test. Frontiers in Psychology, 8, 557.

Shao, Z., Janse, E., Visser, K., \& Meyer, A. S. (2014). What do verbal fluency tasks measure? Predictors of verbal fluency performance in older adults. Frontiers in Psychology, 5, 772.

Sheikh, J. I. \& Yesavage, J. A. (1986). Geriatric depression scale (GDS): Recent evidence and development of a shorter version. In Brink, T. L. Clinical Gerontology: A Guide to Assessment and Intervention (pp. 165174). New York, NY: Haworth Press.

Statistics Korea. (2018, August 27). Population and Housing Census. Statistics Korea. Retrieved from https://www.kostat.go.kr/portal/korea/ kor_nw/3/index.board?bmode $=$ read\&aSeq $=370298$.

Strawbridge, W. J., Wallhagen, M. I., Shema, S. J., \& Kaplan, G. A. (2000). Negative consequences of hearing impairment in old age: A longitudinal analysis. The Gerontologist, 40(3), 320-326.

Wayne, R. V. \& Johnsrude, I. S. (2015). A review of causal mechanisms underlying the link between age-related hearing loss and cognitive decline. Ageing Research Reviews, 23(Pt B), 154-166.

Wiley, T. L., Cruickshanks, K. J., Nondahl, D. M., \& Tweed, T. S. (2000). Selfreported hearing handicap and audiometric measures in older adults. Journal of the American Academy of Audiology, 11(2), 67-75.

Yi, H., Chin, J., Lee, B. H., Kang, Y., \& Na, D. L. (2007). Development and validation of Korean version of trail making test for elderly persons. Dementia and Neurocognitive Disorders, 6(2), 54-66. 